\title{
USING SPORTS EVENTS FOR URBAN REGENERATION IN PORT-SAID
}

\author{
Alaa M. El-Eaishy and Weaam Abdel- Hady Ahmed \\ Architecture Department, Mansura University

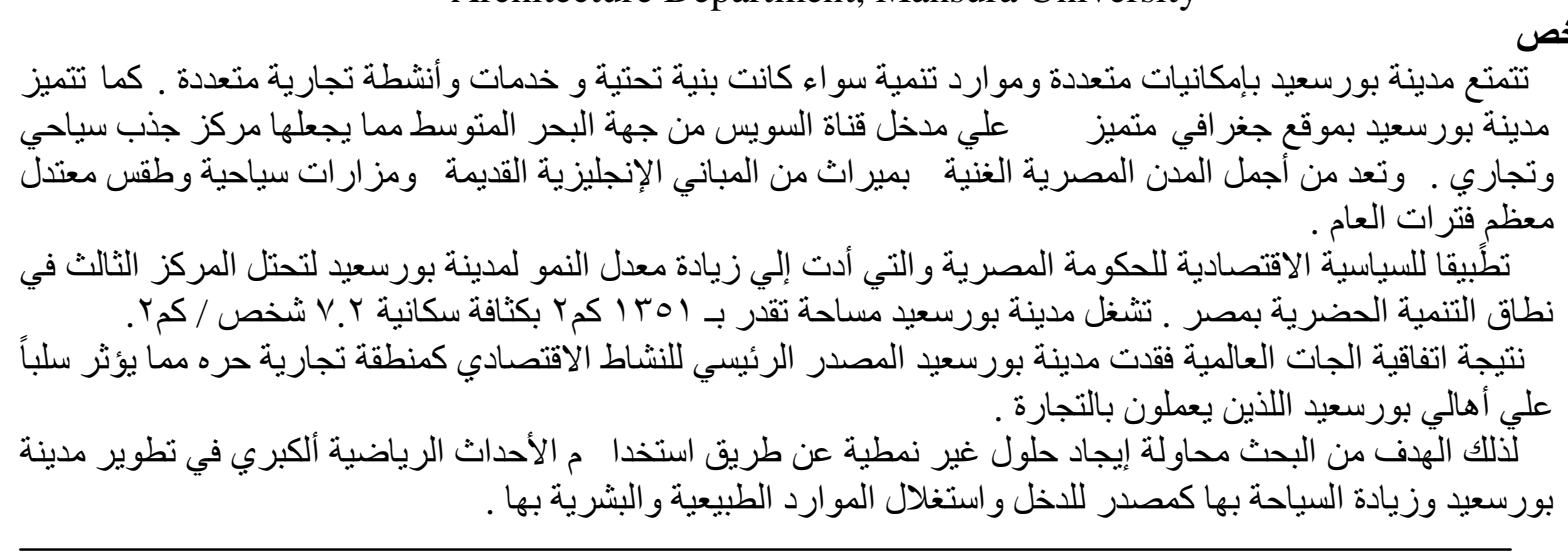 \\ مدينة بورسعيد بإمكانيات متعددة ومو ارد تنمية سو اء كانت بنية تحنية و خدمات و أنشطة تجارية متعددة . كما تتميز مدينة

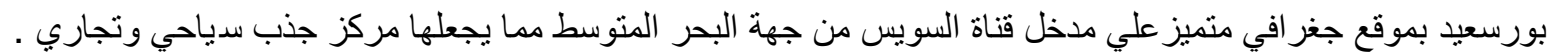

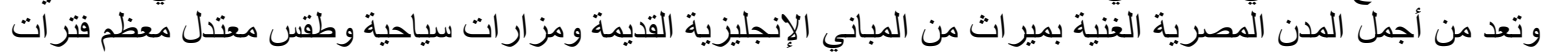

ABSTRACT

Port-Said, in fact, enjoys various types of assets and potentials that could support development, particularly infrastructure, and tourism facilities, services and activities. The location of Port-Said is reflected on its climate, which could be described as Mediterranean. The area is a geological and scenic entity with distinctive characteristics, which is the basis of its attraction for recreation, particularly the Mediterranean shore. Port Said is one of Egypt's most beautiful cities. There are many old houses, giving the city a distinct charm. The unique location of Port-Said could encourage international tourism

Economic policy and potentials accelerated the growth of the governorate. Port-Said became the third largest urban governorate in Egypt. Port-Said governorate extends over an area of approx. $1351 \mathrm{sq} . \mathrm{km}$, with inhabited area of $72.07 \mathrm{sq}$. $\mathrm{km}$ and population density of 7,273 person/sq. km. Port-Said, thus, is facing economic interests.

As a result of the General Agreement of Trade (GAT), Port-Said lost the major economic activities as a tax-free commercial zone this had significant direct impact on Port-Said socio economic development, particularly who involved in trading.

Therefore, the purpose of the research is to investigate the role of sports events led to urban regeneration in Port-Said. The methodology of achieving this purpose includes:

1) Reviewing the concept of urban area development projects

2) Investigating international experience in hosting sports events such as Olympic Games

3) Proposing outlines and recommendations for enhancing sport- led urban regeneration of Port-Said and thus the development of Egypt. 


\section{LITERATURE REVIEW}

\subsection{Urban Area Development}

Urban area development projects (UAD-projects) are a common used instrument to upgrade the urban environment and to give a solution to existing urban problems (like a poor image, deprived areas, social conflicts etc.). UAD-projects consist of integral projects in which many stakeholders, public and private, are involved with many different interests. UADprojects act on different governmental levels, namely local, regional or national.

To deliver urban developments for the benefit of the city and its citizen's urban strategies are designed as leading elements through the whole process. Franzen state that the entire process of urban area development projects is divided into four recognisable phases ${ }^{1}$ :

\begin{tabular}{|c|c|c|c|c|}
\hline INITLATION & BID & PREPRATIONS & $1 \longdiv { 1 }$ EVENT & LEGACY \\
\hline FEW YEARS-DECADES & 2 YEARS & TYEARS & 17 & DECADES \\
\hline
\end{tabular}

Fig(1) Urban area development process

\subsubsection{Olympic Urban Area Development projects}

Development projects organising large-scale sports events, have become part of urban strategies by governments to improve the urban structure, to promote the city's image in an international showcase and create economic growth. These major events generate attention, investments and potential for the organising city and thus act as a development engine. Many cities showed that even without actually hosting such a major event a city could already benefit from the catalytic-effect to speed up existing urban developments. Table (1) gives a clear overview of the increasing number of urban investment generated by hosting the Olympics.

\footnotetext{
${ }^{1}$ Franzen, A., Hobma, F., de Jonge, H. \& Wigmans, G. (2011) Management of Urban Development Processes in the Netherlands, Delft
} University of Technology, Delft. 


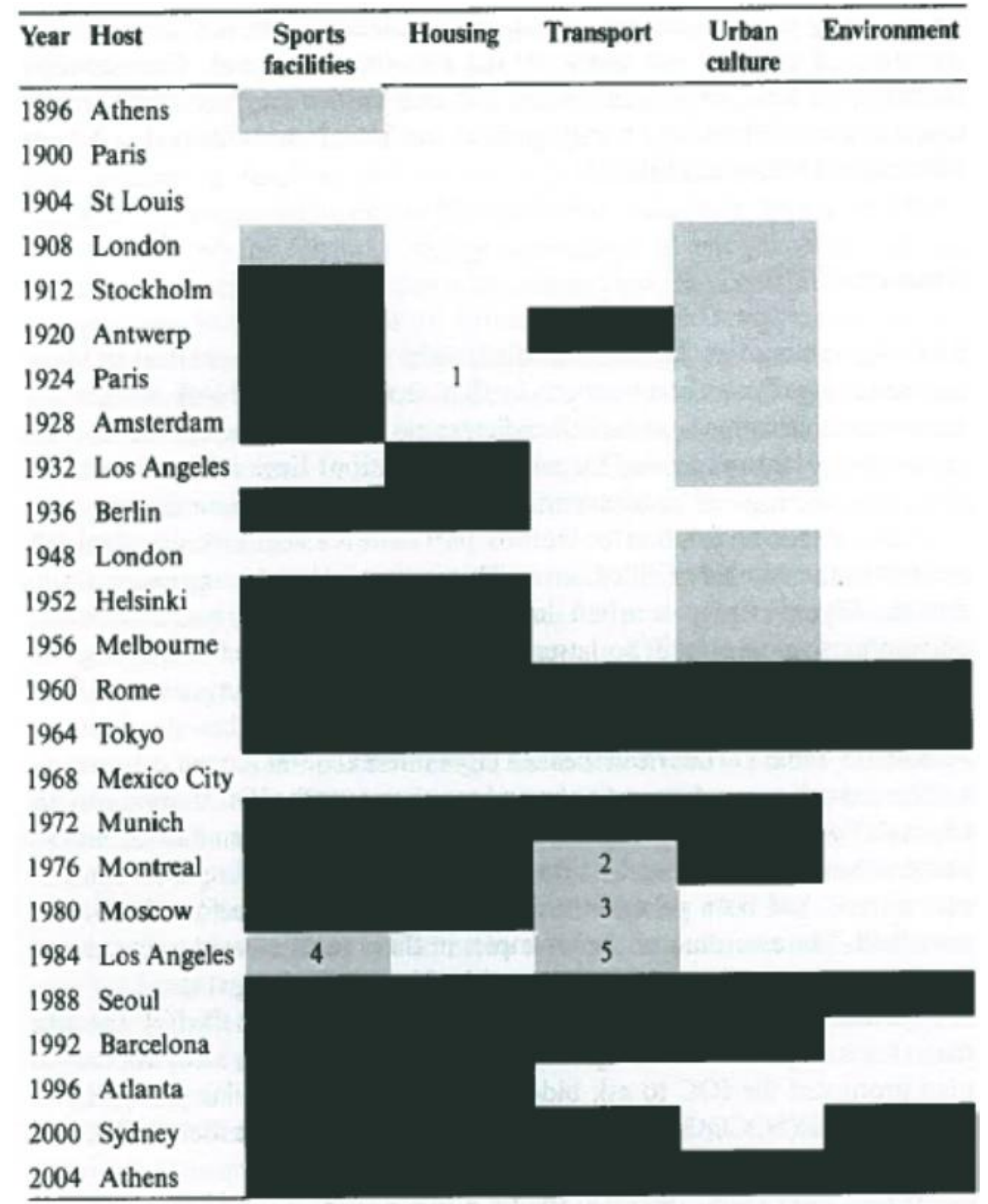

Table (1) History of urban investment by sector: Olympic Games 1892-2004 ${ }^{2}$

\footnotetext{
${ }^{2}$ Poynter, G. \& MacRury, I. (2009) Olympic Cities: 2012 and the Remaking of London, University of East London, Ashgate, UK
} 
Time in an Olympic city can be divided into three period's table (2). There is the pre-Games period, developing a successful bid plan and then organising the Games. Secondly, there is Games period with a duration of three weekends and two. The post- Games period is by far the longest; it stretches for decades after the Games. However, it is clearly the least-planned period3.

\begin{tabular}{|c|c|c|}
\hline Olympic Periods & Consists of & Duration \\
\hline P're-liames period & $\begin{array}{l}\text { deve]op a success[ul oid plan and then } \\
\text { organising the Games themselves }\end{array}$ & belween $/$ - 15 years \\
\hline The Games period & $\begin{array}{l}\text { The revent. itscll, matches, modial } \\
\text { teremonies elc: }\end{array}$ & 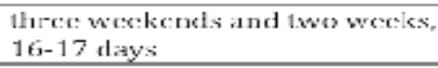 \\
\hline Post-Games period & after-use of the vemues & many decades \\
\hline
\end{tabular}

Table (2): Cashman, 1998

In the beginning of the 20th century Olympic host cities only had to invest in upgrading existing sporting facilities and a few new venues. The amount of spectators, media and athletes was acceptable and applicable without large urban improvements. Nowadays, costs for infrastructural improvements rise and cities have to better plan the after-use of the Games to prevent new facilities from being left unused and the Olympic park from becoming abandoned.

In figure (1) the Olympic process is divided into five distinct phases. The intention to bid for the Olympics starts by the local or national government or a public leader. Reasons used by many cities: international prestige, promotion of national strength and unity, city beautification, re-development of deprived areas and improvement of the economy.

Applicant cities then have to deliver the applicant documents and if approved they are added to the candidate shortlist. The next step is to create a bid. Cities have less than a year then to establish a plan for hosting the event. After cities delivered their bid books, the evaluation commission of the IOC5 makes some visits to the candidate cities to analyse if their bids are realistic and which one is most in favour of hosting the Games.

\subsubsection{Legacy planning}

The IOC describes Olympic legacy as 'multi-disciplinary and dynamic and is affected by a variety of local and global factors. Therefore, it is a local and global concept, existing within cities, regions and nations, as well as internationally'. So, it is clear that legacy indicates something that is left behind after, in this case the Olympic Games. The IOC Charter, states that the role of the IOC is "to promote a positive legacy from the Olympic Games to the host cities and host countries"

Legacy is being associated with impact on physical and non-physical levels ${ }^{5}$. Legacies can be planned and unplanned, positive and negative. Finally, the same legacy may be positive for one industry (e.g. tourism) and negative for another (e.g. the environment). The same legacy maybe viewed positively or negatively, depending on who is making the assessment ${ }^{6}$.

\footnotetext{
${ }_{3}^{3}$ Cashman, R. (1998) Olympic Legacy in an Olympic City: Monuments, Museums and Memory. University of New South Wales, Australia

${ }^{4}$ International Olympic Commitee (8th July 2011) The Olympic Charter, Lausanne, Switzerland Rule 2, Article 14.

${ }^{5}$ Gold, J.R. \& Gold, M.M. (2007) Olympic cities- City Agendas, Planning and the World's Games, 1896-

2012. Routledge, New York, United States of America (draft gevonden chapter 17:LONDON)

${ }^{6}$ Preuss, H. (2006) Lasting effects of Major Sporting Events. Institute of Sports Science,

Johannes Gutenberg-Universitat Mainz, Germany
} 


\section{RESEARCH METHODOLOGY}

In the next section a site analysis will be conducted. In order to determine the best location for urban development, the city attractions will be mapped through multiple location options and therefore assessed.

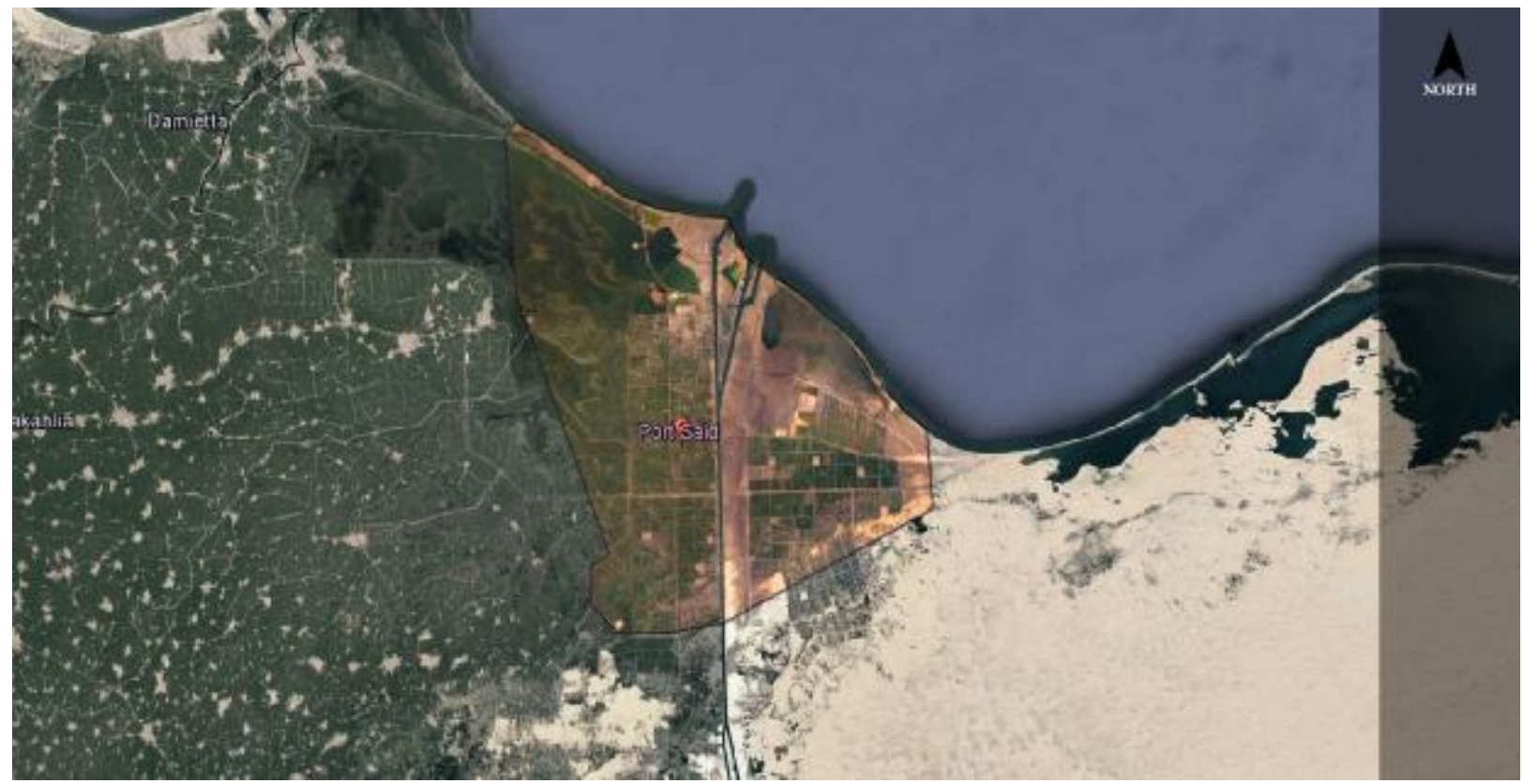

Fig (2) Port Said Governorate borders

\subsection{Urban Development}

The fast urban expansion of the city was controlled by an urban development plan, reflecting the contemporary French model for new towns. The regular plan was implemented by the Suez Canal Company (today Suez Canal Authority), from 1861 on. Its urban grid was oriented parallel to the axis of the future Suez Canal and aligned towards the coastline of the Mediterranean Sea in the north. The vast octagonal plan, with its rectangular street grit of 15 and 30 meters wide streets, was firstly built without a division into plots.

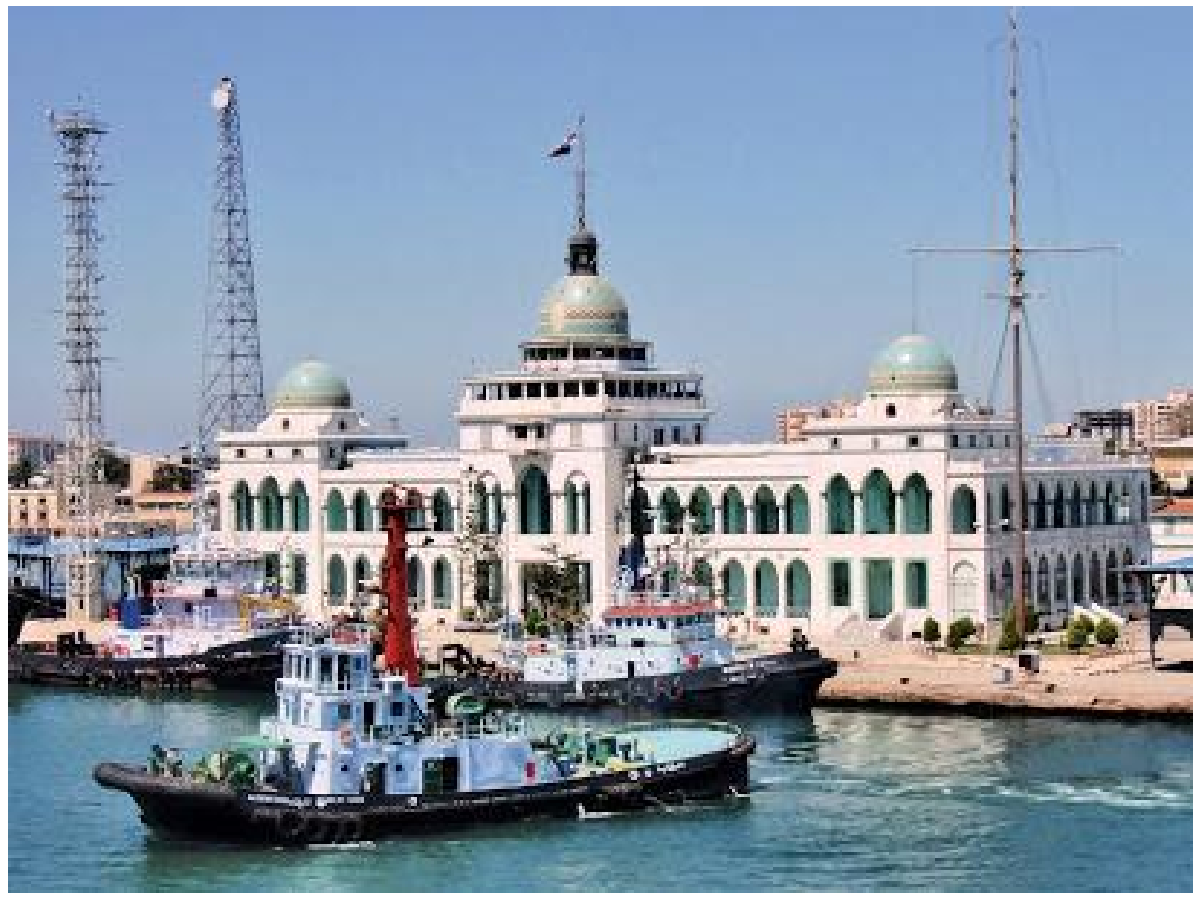

Fig (3). Suez Canal Authority 
USING SPORTS EVENTS FOR URBAN REGENERATION IN PORT-SAID

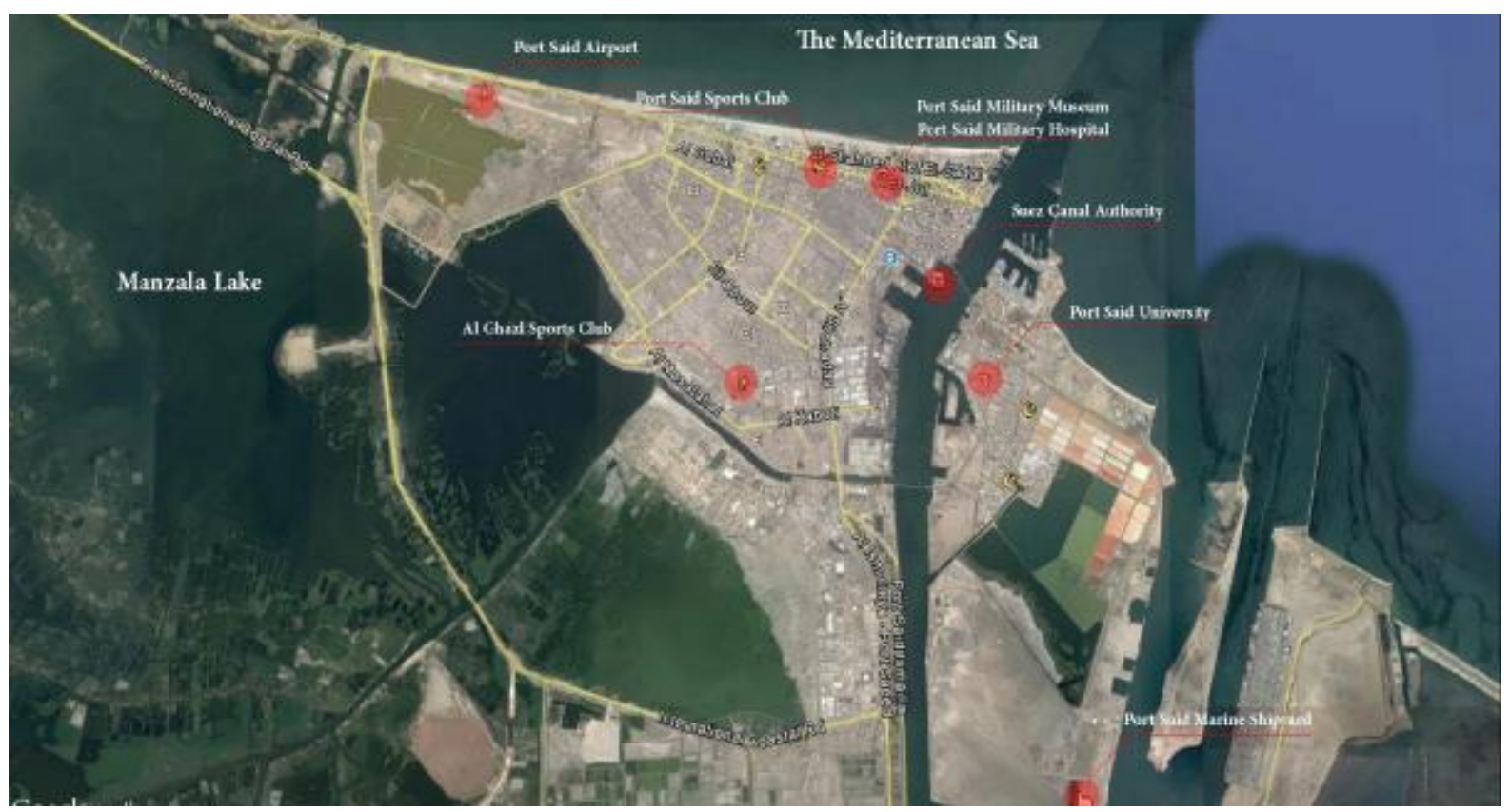

Fig(4-1) Port Said Major Landmarks

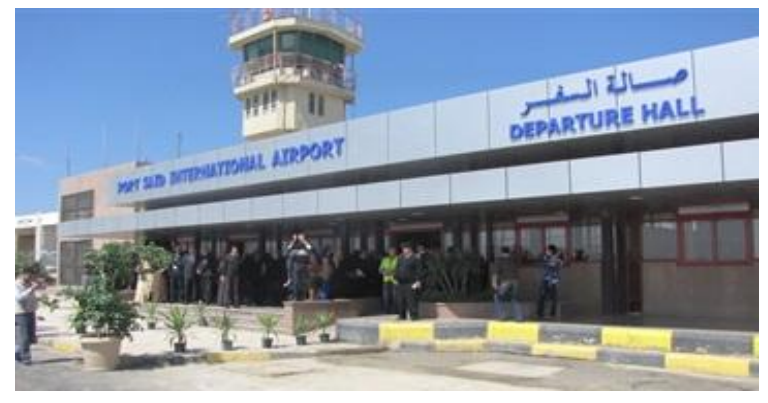

Fig (4-2) Port Said Airport

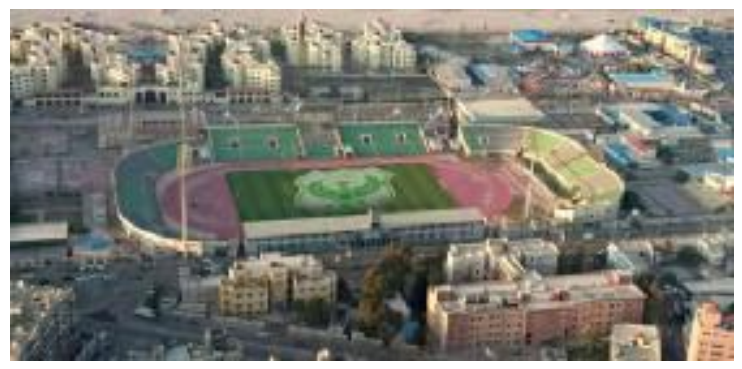

Fig (4-3) Port Said Sports Club

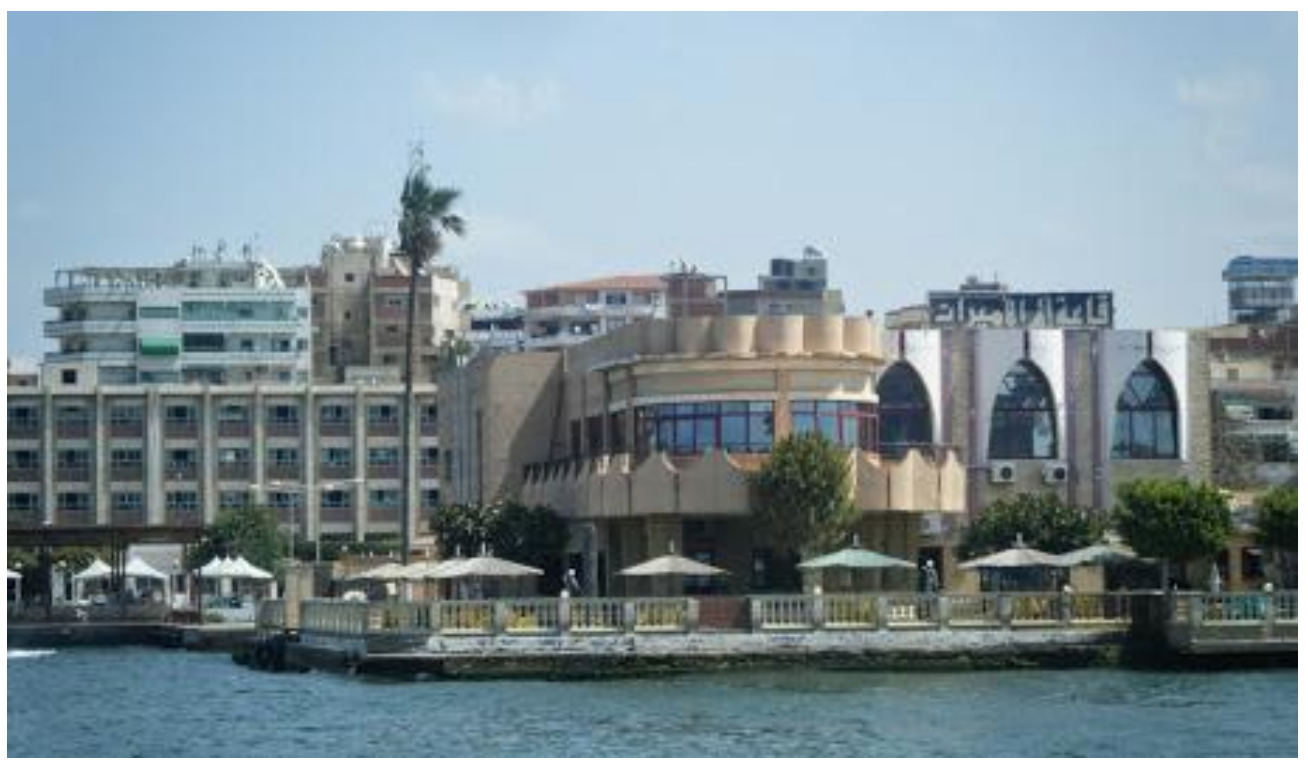

Fig (4-4) Port Said Military Museum

Fig (4) Port Said Major Landmarks 


\subsubsection{Option A}

The selection of this place for the Olympic city is based on some nearby facilities, first of them is Port Said Airport which connects the other countries with Egypt. Then International Costal Road which connects the other cities with Port Said, also this place is very nearby to the Mediterranean Sea.

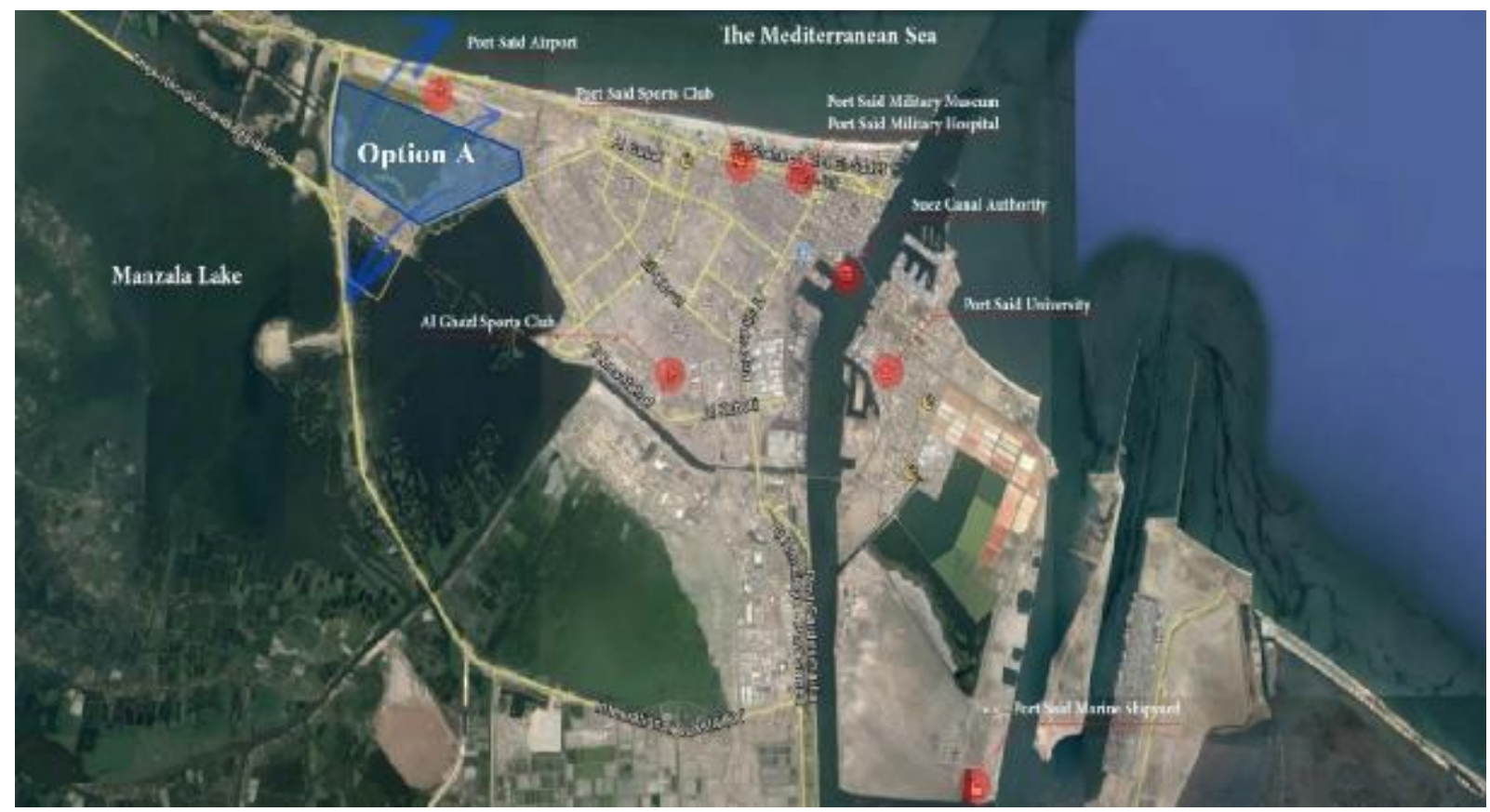

Fig(5) Proposed Olympic city location analysis (OPTION A)

\subsubsection{Option B}

This place is selected to be for the Olympic City because of it is so near to the International Costal Road also Al-Ismailia - Port Said Road.

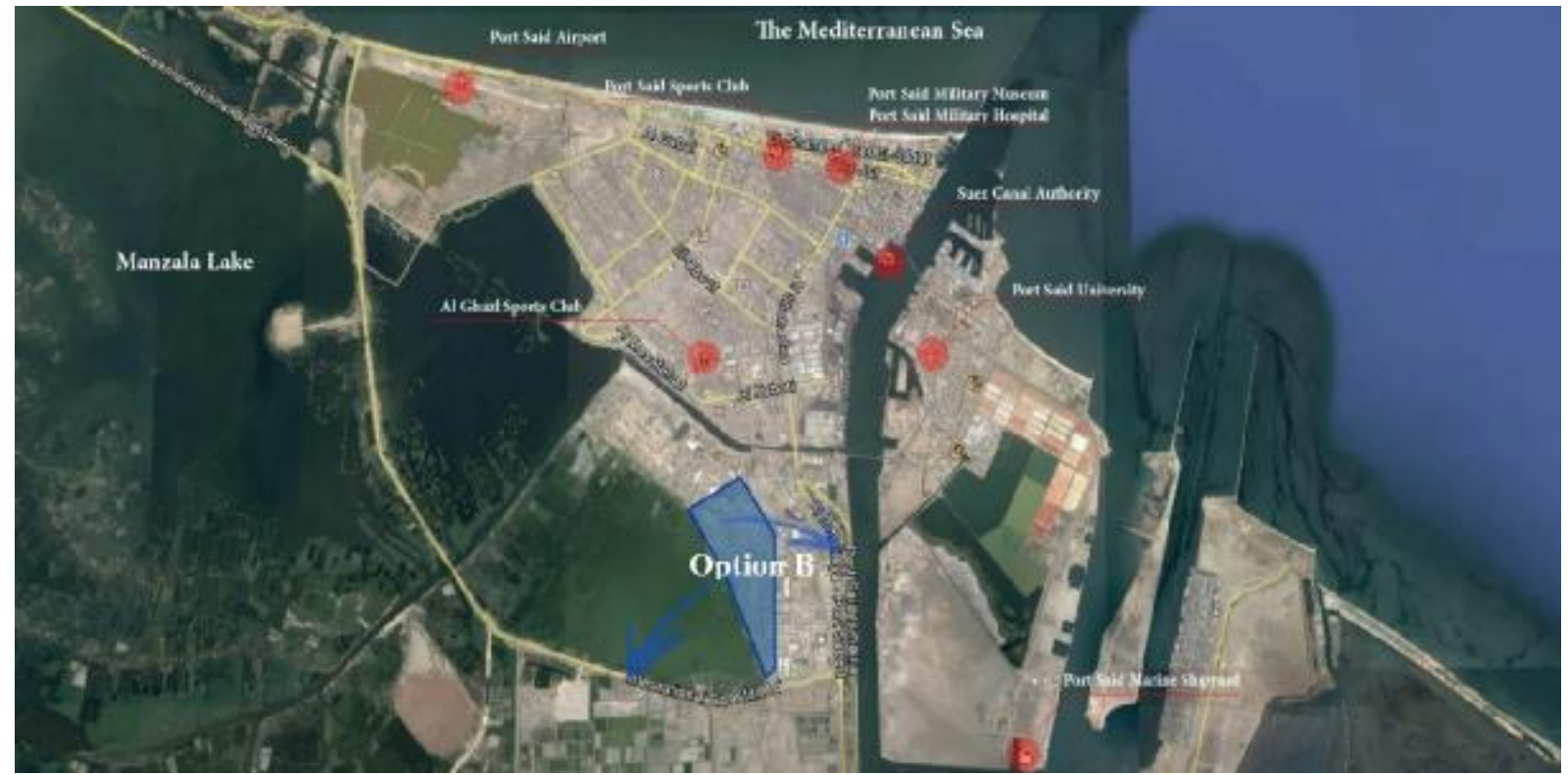

Fig(6) Proposed Olympic city location analysis (OPTION B) 


\subsubsection{Option C}

Also this option is selected to be for the Olympic city because of being nearby to the International Costal Road also Al-Ismailia - Port Said Road.

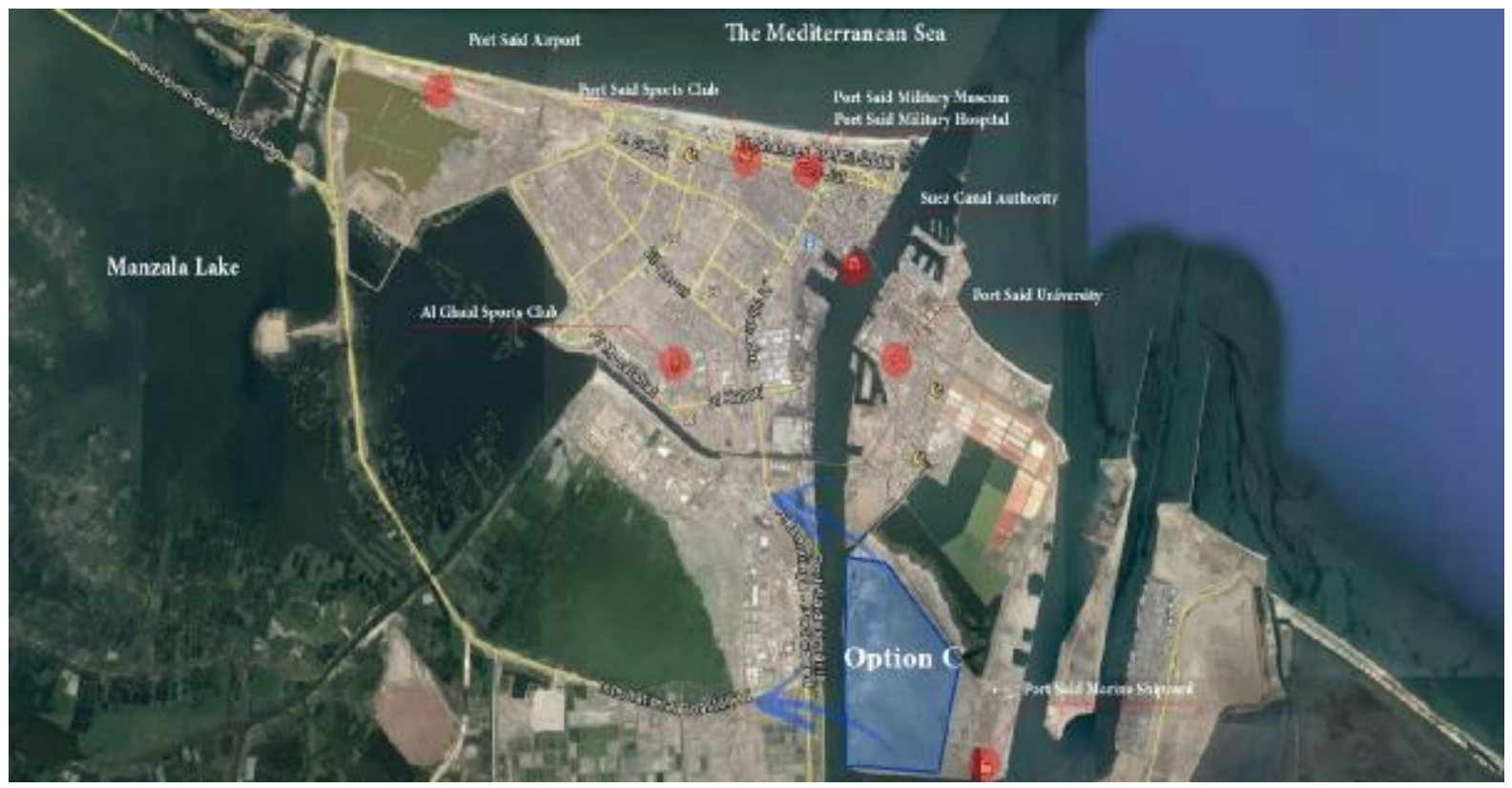

Fig(7) Proposed Olympic city location analysis (OPTION C)

\subsubsection{Option D}

This place is recommended to be the Olympic City because of there are a lot of facilities which it will make this place very privileged, the International Costal Road is the first facility which connects this place to Port Said Airport, also connects it with the other cities. Also there is an important train station which it will connect other cities to Port Said as it will make a different in urban development as for the Olympic city.

This place is considered to be unique as there are a lot of sport facilities, Al Ghazi sports club, Al Their Indoor Hall, Al Mareekh sports club also al Salam sports Club . As for the commercial facilities this place is too near to the old commercial city.

Hosting is also main point as this location has a lot of new housing zones and inactive lands which can be used to build new hosting facilities to host the Olympic events

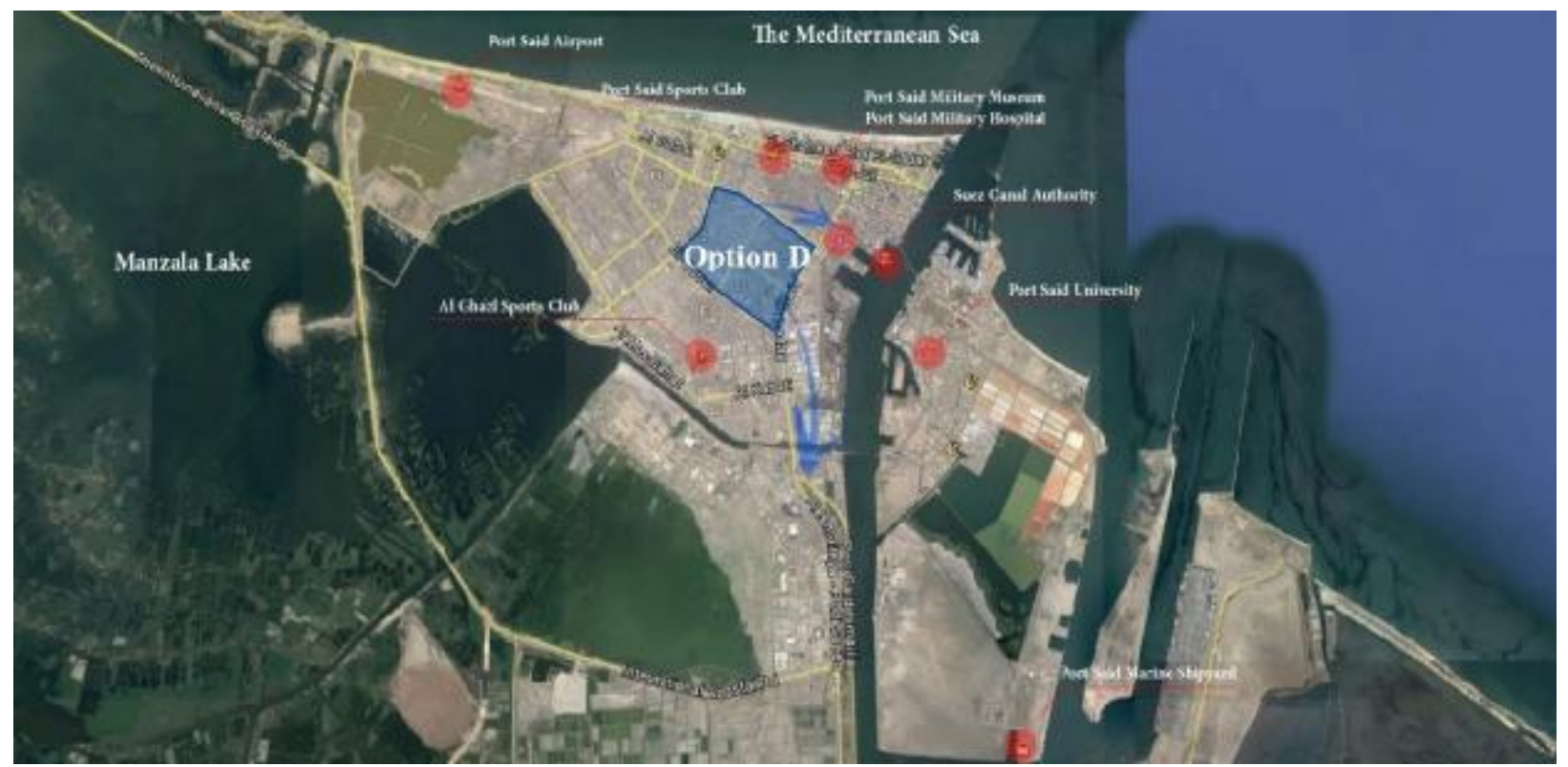

Fig(8) Proposed Olympic city location analysis (OPTION D) 


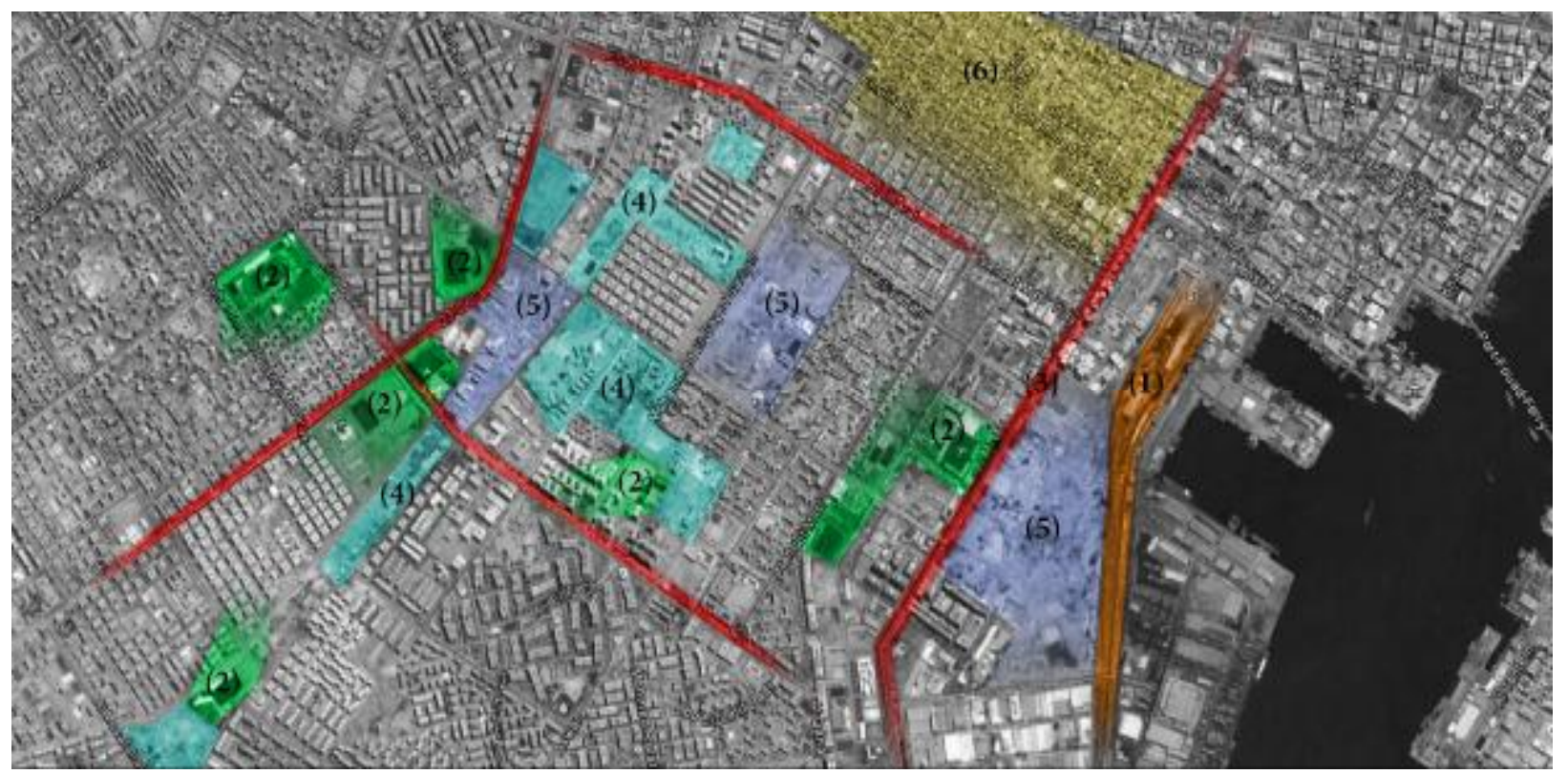

Fig(9) Proposed Olympic city location analysis (OPTION D - details)

\section{FINDINGS \& RECOMMENDATIONS}

The legacy was described as 'something left behind by a predecessor', it could be planned or unplanned, tangible or intangible. This definition has a negative association since it contained venues and facilities that were built for the Olympics and mostly did not have a clear after-use. In the next paragraphs strategies for future sports events host cities will be explained:

\subsection{Strategies}

In this part the urban legacy strategies will be summarised and divided into the four strategic activities and briefly explained.

\subsubsection{Visioning}

The strategic activity visioning forms the starting point of the Olympic process and needs to be taken into account during each phase.

- Incorporate the Olympic plan into the existing urban plans for Port-Said

- Integrate sustainable developments into future developments of Port-Said

- Negotiate, tailor and steer on local demands for an optimal legacy

- Get the people of Port-Said involved and give them influence

\subsubsection{Planning}

- Incorporate the legacy plan in an early phase of planning

- Create a planning framework that can respond to changes in the market

- Make use of changes in Port-Said urban context

- Create Olympic regulations to speed up the process

\subsubsection{Venturing}

- Choose a strategic location

- Own or control strategic land

- Get early acquisition of the land and planning permissions

- Make use of temporary and existing facilities

- Be clear about the costs and guarantee continuing investments

\subsubsection{Learning}

- Strong governmental control is necessary for successful integration of legacy objectives

- Use skilled people with expertise from preceding games or previous (local) project

- Develop and integrate an organisation responsible for the legacy

- Transfer knowledge from past sports events 


\section{4-REFERENCES:}

1. Magdy M. El-Bastawisy, Abd-Al-Whab Helmy, Rania H. Ali Integrated socio-economic development for accelerating regional role of Port-Said in tourism development of Egypt 42nd ISoCaRP Congress 2006

2. Franzen, A., Hobma, F., de Jonge, H. \& Wigmans, G. (2011) Management of Urban Development Processes in the Netherlands, Delft University of Technology, Delft.

3. Poynter, G. \& MacRury, I. (2009) Olympic Cities: 2012 and the Remaking of London, University of East London, Ashgate, UK

4. Cashman, R. (1998) Olympic Legacy in an Olympic City: Monuments, Museums and Memory. University of New South Wales, Australia.

5. International Olympic Commitee (8th July 2011) The Olympic Charter, Lausanne, Switzerland.

6. Gold, J.R. \& Gold, M.M. (2007) Olympic cities- City Agendas, Planning and the World's Games, 1896-2012. Routledge, New York, United States of America (draft gevonden chapter 17:LONDON)

7. Preuss, H. (2006) Lasting effects of Major Sporting Events. Institute of Sports Science,

\section{5- Figures:} Johannes Gutenberg-Universitat Mainz, Germany

1- Fig(1) Urban area development process

2- Fig (2) Port Said Governorate borders

3- Fig (3). Suez Canal Authority

4- Fig (4) Port Said Major Landmarks

A. Fig(4-1) Port Said Major Landmarks

B. Fig (4-2) Port Said Airport

C. Fig (4-3) Port Said Sports Club

D. Fig (4-4) Port Said Military Museum

5- Fig(5) Proposed Olympic city location analysis (OPTION A)

6- Fig(6) Proposed Olympic city location analysis (OPTION B)

7- Fig(7) Proposed Olympic city location analysis (OPTION C)

8- Fig (8) Proposed Olympic city location analysis (OPTION D)

9- Fig(9) Proposed Olympic city location analysis (OPTION D - details)

\section{6- Tables:}

1- Table (1) History of urban investment by sector: Olympic Games 1892-2004 ${ }^{7}$

2- Table (2): Cashman, 1998.

\footnotetext{
${ }^{7}$ Poynter, G. \& MacRury, I. (2009) Olympic Cities: 2012 and the Remaking of London, University of East London, Ashgate, UK
} 